\title{
Plasma lactate dehydrogenase in megaloblastic anaemia
}

\author{
C. F. McCARTHY, I. D. FRASER ${ }^{1}$, AND A. E. READ \\ From the Departments of Medicine and Haematology, Royal Infirmary, Bristol
}

SYNOPSIS Raised plasma lactate dehydrogenase (LDH) values were found in 26 patients with marked megaloblastic anaemia due either to vitamin $B_{12}$ or folic-acid deficiency or a combination of these factors.

Minor megaloblastic changes were not usually accompanied by plasma LDH elevation. Serial LDH estimations were as valuable as serial reticulocyte counts in assessing the response to physiological doses of folic acid and therefore in deciding whether megaloblastic anaemia is partially or completely due to folic acid deficiency.

Elevation of plasma lactate dehydrogenase concentration (LDH) is known to occur in patients with megaloblastic anaemia. The literature on this subject is reviewed by Hess (1963) and the value of LDH estimations as a screening test in the detection of megaloblastic anaemia during pregnancy is commented on by Fleming and Elliott (1964).

Our studies were carried out to provide further information on LDH levels in megaloblastic anaemia and to evaluate the usefulness of serial estimations in assessing the response to physiological amounts of folic acid, and thus as a test of folic acid deficiency.

\section{PATIENTS AND METHODS}

Three-hundred and seventy-three LDH estimations were carried out on the following groups of patients:Twenty-seven patients whose bone marrow showed marked megaloblastic changes; 10 patients whose marrow showed minimal megaloblastic or megaloblastoid change; 27 post-gastrectomy patients with and without anaemia; 16 patients with miscellaneous conditions, mainly peptic ulcer or neurosis, who served as a control group.

In 13 of the patients with megaloblastic anaemia the haematological response to $50 \mu \mathrm{g}$. of folic acid daily was studied. Nine of these had predominant vitamin $\mathbf{B}_{12}$ deficiency, four folic acid deficiency. The folic acid was given intramuscularly to the patients with malabsorption and orally to the others. Reticulocytes and plasma LDH were estimated daily, haemoglobulin and packed cell volume on alternate days. When steady base-line values for reticulocytes were obtained the folic acid was started and continued for 10 days except where otherwise stated in the test. These patients were on a white diet containing in-

${ }^{1}$ Present address: Cheltenham General Hospital.

Received for publication 24 September 1965. sufficient folic acid or $B_{12}$ to cause a reticulocyte response during the period of folic acid administration.

URINARY FORMININO-GLUTAMIC ACID (FIGLU) An oral loading dose of $15 \mathrm{~g}$. of $\mathrm{L}$-histidine was given and the urinary excretion of Figlu was measured by conventional voltage electrophoresis on cellulose acetate (Kohn, Mollin, and Rosenbach, 1961). Although the method is not quantitative a rough grading of the Figlu spot was made:,+++ , +++ . It has been shown that +++ represents a urinary Figlu concentration greater than $500 \mu \mathrm{g} . / \mathrm{ml}$.

Serum folate levels were measured by microbiological assay ( $L$. casei ATCC 746), the normal range being 5.9 to $21 \mathrm{~m} \mu \mathrm{g} . / \mathrm{ml}$. Serum vitamin $B_{12}$ levels were measured by microbiological assay (L. leichmanii), the normal range being 140 to $900 \mu \mu \mathrm{g}$. $/ \mathrm{ml}$.

Lactate dehydrogenase was estimated as described by Berger and Broida (1964). The normal value quoted by these authors is 100 to 350 units per ml., 350 to 500 being borderline, and above this abnormal. As some of our control group had values up to 500 units per ml. we have taken this figure as the upper limit of normal.

MARROW REASSESSMENT The initial marrow films in 10 patients (Table I) were reported to show mild megaloblastic or megaloblastoid changes. These marrow films were re-examined by one of us and a rough grading of the degree of megaloblastic change present was made. For this purpose the red and white cell precursors were separated and the grading was carried out as follows:Megaloblastic changes present at all stages of red cell development +++ ; changes present in only a few intermediate and late normoblasts + , changes intermediate between + and +++ were designated ++ . When numerous macropolycytes and giant metamyelocytes were present the white cell series was designated +++ , when only a few macropolycytes and giant metamyelocytes were present + , and intermediate changes ++ . 
The term megaloblastoid (M) was used to describe the marrow appearance when red cell precursors showed slight asynchronism between nuclear and cytoplasmic maturation, no Howell Jolly bodies were present, and the white cell series was normal.

\section{RESULTS}

The LDH values of patients whose marrows showed marked megaloblastic changes are shown in Figure 1. All values were above the normal range.

The haematological data and the results of reassessment of the marrow picture, together with the type of treatment of the 10 patients whose marrow was initially reported as showing mild megaloblastic or megaloblastoid change, are shown in Table I.

Two patients had LDH values greater than normal. Case 1 had post-gastrectomy vitamin $B_{12}$ deficiency and required vitamin $B_{12}$ before the haemoglobin level rose. Case 3 was a fit 47 -year-old man who had persistently elevated levels although significant vitamin $B_{12}$ or folic acid deficiency was not present. His haemoglobin rose rapidly when intravenous iron was given and LDH fell to normal levels.

EFFECTS OF TREATMENT WITH PHYSIOLOGICAL AMOUNTS OF FOLIC ACID ON LDH VALUES IN PATIENTS WITH MEGALOBLASTIC ANAEMIA. Details of patients with predominant vitamin $B_{12}$ deficiency are given in Table II. In six patients (1 to 6) there was no increase in haemoglobin, packed cell volume, reticulocyte count, nor was there any significant change in LDH level during the 10-day period of treatment with physiological doses of folic acid. One patient (no. 7) developed a

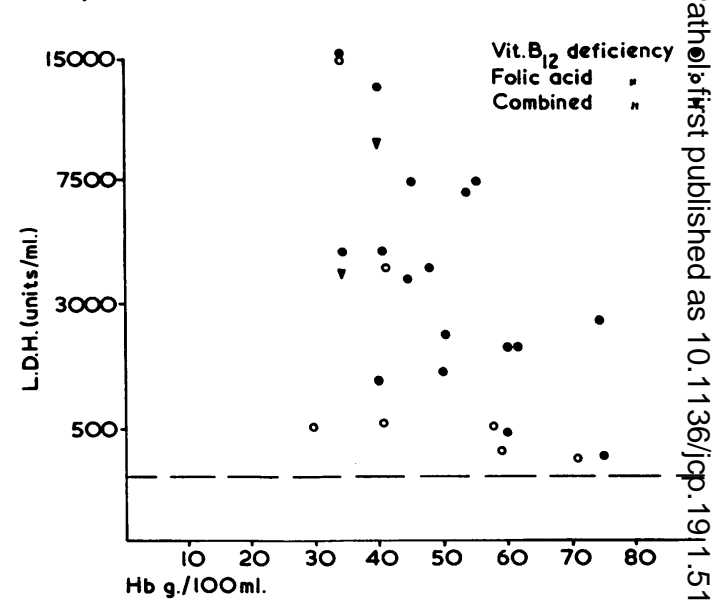

FIG. 1 Plasma LDH levels in patients with markedy megaloblastic bone marrow $(14.6 \mathrm{~g} .=100)$.

$10 \%$ increase in reticulocyte count without a fallọn LDH level but she was unusual in that her reticulocyte count on admission to hospital was $7 \%$ and the serum contained large amounts of methhaemalbumin. Over a few days the reticulocyte count fell toa base line value of 3 to $4 \%$ without a change in the methhaemalbumin concentration, but with a $5 / 0$ fall in haemoglobin level. The folate level and Figi excretion in this patient did not suggest folic a.gd deficiency.

In two patients (cases 8 and 9) considera alteration in LDH occurred associated with reticlocyte changes. In case 8 the LDH fell from a pretreatment level of 4,000 units to 2,000 and this fall

TABLE I

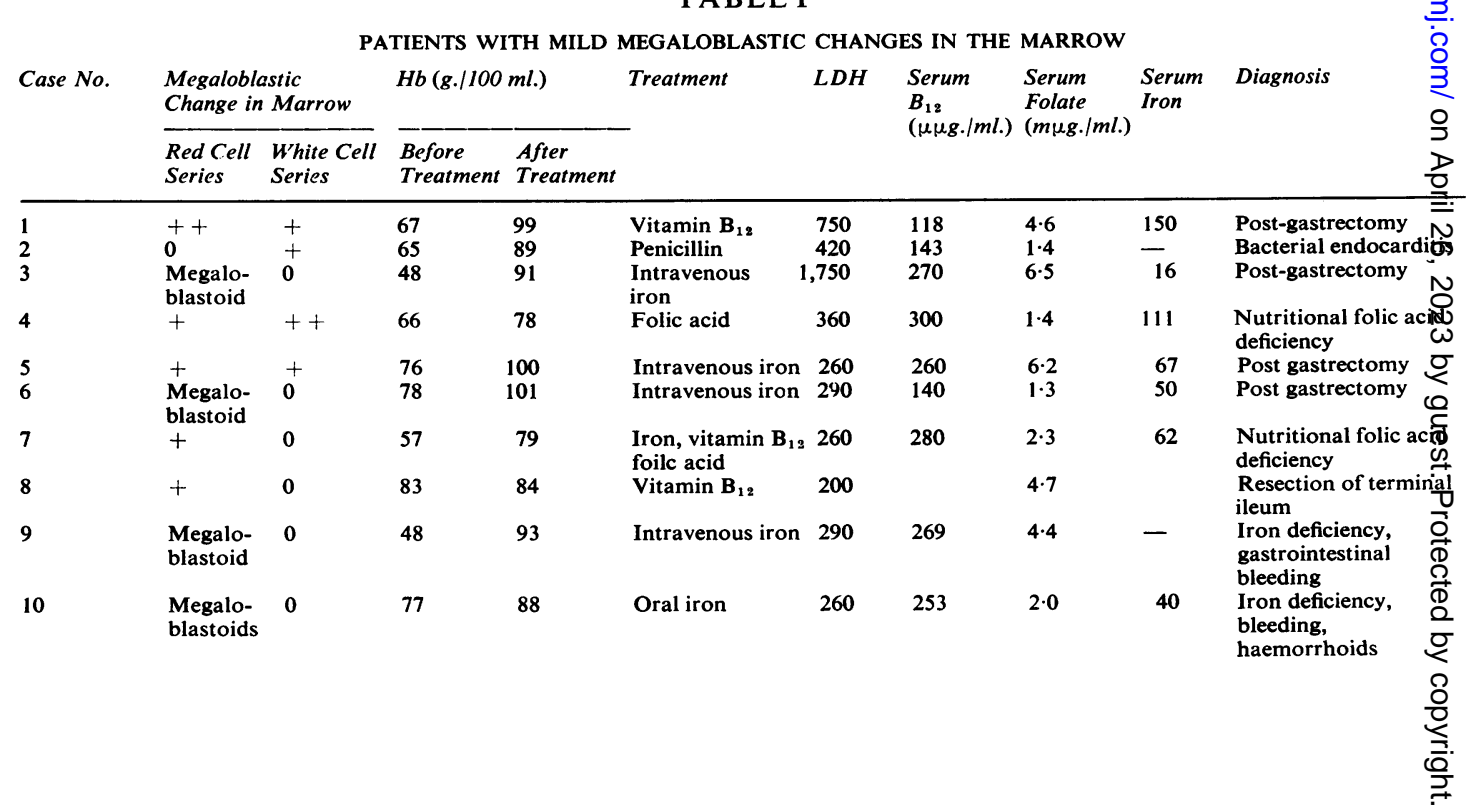


TABLE II

\begin{tabular}{|c|c|c|c|c|c|c|c|c|c|}
\hline \multirow[t]{2}{*}{$\begin{array}{l}\text { Case } \\
\text { No. }\end{array}$} & \multicolumn{2}{|c|}{$\begin{array}{l}\text { Haemoglobin } \\
(\mathrm{g} . / 100 \mathrm{ml} .)\end{array}$} & \multicolumn{2}{|l|}{$L D H$} & \multirow{2}{*}{$\begin{array}{l}\text { Serum } \\
\text { Vitamin } B_{12} \\
(\mu \mu g . / m l .)\end{array}$} & \multirow{2}{*}{$\begin{array}{l}\text { Serum } \\
\text { Folate } \\
(m \mu g . / m l .)\end{array}$} & \multirow[t]{2}{*}{ Figlu } & \multirow[t]{2}{*}{$\begin{array}{l}\text { Schilling } \\
\text { Test }(\%)\end{array}$} & \multirow[t]{2}{*}{ Diagnosis } \\
\hline & $\begin{array}{l}\text { Before } \\
\text { Treatment }\end{array}$ & $\begin{array}{l}\text { After } \\
\text { Treatment }\end{array}$ & $\begin{array}{l}\text { Before } \\
\text { Treatment }\end{array}$ & $\begin{array}{l}\text { After } \\
\text { Treatment }\end{array}$ & & & & & \\
\hline $\begin{array}{l}1 \\
2 \\
3 \\
4 \\
5 \\
6 \\
7 \\
8 \\
9\end{array}$ & $\begin{array}{l}55 \\
53 \\
47 \\
40 \\
48 \\
60 \\
40 \\
35 \\
40\end{array}$ & $\begin{array}{l}40 \\
49 \\
42 \\
38 \\
50 \\
55 \\
32 \\
37 \\
32\end{array}$ & $\begin{array}{r}8,000 \\
5,050 \\
3,750 \\
1,650 \\
2,250 \\
2,200 \\
12,500 \\
4,000 \\
10,000\end{array}$ & $\begin{array}{r}8,700 \\
6,400 \\
4,200 \\
1,700 \\
1,850 \\
2,300 \\
17,500 \\
2,000 \\
5,200\end{array}$ & $\begin{array}{r}10 \\
75 \\
70 \\
57 \\
50 \\
94 \\
110 \\
95 \\
104\end{array}$ & \begin{tabular}{r|}
$3 \cdot 4$ \\
$5 \cdot 8$ \\
$20 \cdot 9$ \\
$2 \cdot 6$ \\
$3 \cdot 5$ \\
$3 \cdot 5$ \\
$8 \cdot 5$ \\
$8 \cdot 2$ \\
$2 \cdot 7$
\end{tabular} & $\begin{array}{l}\text {-ve } \\
\text {-ve } \\
\text {-ve } \\
+ \\
++ \\
+ \\
+ \\
+++ \\
+++\end{array}$ & $\begin{array}{l}1 \cdot 32 \\
1 \cdot 7 \\
0 \cdot 14 \\
0 \cdot 14 \\
0 \cdot 2 \\
4 \\
0 \cdot 9 \\
0 \cdot 5 \\
1 \cdot 2\end{array}$ & $\begin{array}{l}\text { Pernicious anaemia } \\
\text { Pernicious anaemia } \\
\text { Pernicious anaemia } \\
\text { Pernicious anaemia } \\
\text { Pernicious anaemia } \\
\text { Post-gastrectomy } \\
\text { Pernicious anaemia } \\
\text { Pernicious anaemia } \\
\text { Pernicious anaemia }\end{array}$ \\
\hline
\end{tabular}

${ }^{1}$ Ten days' oral folic acid, $50 \mu g$. a day.

TABLE III

PATIENTS WITH FOLIC ACID DEFICIENCY

\begin{tabular}{|c|c|c|c|c|c|c|c|c|}
\hline \multirow[t]{2}{*}{$\begin{array}{l}\text { Case } \\
\text { No. }\end{array}$} & \multicolumn{2}{|c|}{$\begin{array}{l}\text { Haemoglobin } \\
(\mathrm{g} . / 100 \mathrm{ml} .)\end{array}$} & \multicolumn{2}{|l|}{$L D H$} & \multirow{2}{*}{$\begin{array}{l}\text { Serum } \\
\text { Vitamin } B_{18} \\
(\mu \mu g . / m l .)\end{array}$} & \multirow{2}{*}{$\begin{array}{l}\text { Serum } \\
\text { Folate } \\
(m \mu g . / m l .)\end{array}$} & \multirow[t]{2}{*}{ Figlu } & \multirow[t]{2}{*}{ Diagnosis } \\
\hline & $\begin{array}{l}\text { Before } \\
\text { Treatment }\end{array}$ & $\begin{array}{l}\text { After } \\
\text { Treatment }\end{array}$ & $\begin{array}{l}\text { Before } \\
\text { Treatment }\end{array}$ & $\begin{array}{l}\text { After } \\
\text { Treatment }\end{array}$ & & & & \\
\hline $\begin{array}{l}1 \\
2 \\
3 \\
4\end{array}$ & $\begin{array}{l}42 \\
58 \\
42 \\
35\end{array}$ & $\begin{array}{l}60 \\
66 \\
61 \\
50\end{array}$ & $\begin{array}{r}3,900 \\
720 \\
1,290 \\
15,000\end{array}$ & $\begin{array}{r}500 \\
390 \\
520 \\
4,000\end{array}$ & $\begin{array}{r}95 \\
260 \\
190 \\
210\end{array}$ & $\begin{array}{l}2 \cdot 7 \\
1 \cdot 8 \\
1 \cdot 2 \\
1 \cdot 4\end{array}$ & $\begin{array}{l}+++ \\
\text { nd } \\
\text { nd } \\
++\end{array}$ & $\begin{array}{l}\text { Idiopathic steatorrhoea } \\
\text { Idiopathic steatorrhoea } \\
\text { Nutritional folic acid deficiency } \\
\text { Nutritional folic acid deficiency }\end{array}$ \\
\hline
\end{tabular}

was associated with a $14 \%$ increase in reticulocytes. By the twelfth day the reticulocyte count had fallen to baseline levels. Three further LDH values at this time were approximately 2,000 . No alteration of haemoglobin level occurred during these 12 days. In case 9 a similar response occurred during the first 10 days; the LDH values fell by just under 5,000 units in association with a reticulocytosis. The $\mathrm{LDH}$ values were followed for a further 20 days during which folic acid in physiological doses was continued. During this time the LDH value rose gradually to the pre-treatment value of 10,000 . The haemoglobin level did not rise during the period of observation. These two patients had strongly positive Figlu tests and were considered to have combined deficiency of vitamin $B_{12}$ and folic acid. All of these patients then responded promptly to vitamin $B_{12}$ and the $L D H$ values fell to normal.

PATIENTS WITH FOLIC ACID DEFICIENCY The details, the effect of 10 days' oral or intramuscular therapy and with $50 \mu \mathrm{g}$. of folic acid on these patients, are shown in Table III. In the four patients a fall in LDH accompanied by a rise in the reticulocytes occurred. Further folic acid therapy resulted in the LDH levels falling to normal.

Possible relationships between LDH and serum levels of vitamin $B_{12}$ and folic acid are explored in Tables IV and V but no correlation was detected.

\section{DISCUSSION}

In common with the findings of others the LDH levels in our patients with marked megaloblastic changes in their bone marrow were considerably raised above normal. Patients with slight megaloblastic changes usually had normal levels. This latter

\section{TABLE IV}

SERUM FOLATE, VITAMIN $B_{12}$, AND LDH VALUES IN NONMEGALOBLASTIC PATIENTS

\begin{tabular}{|c|c|c|c|c|}
\hline & \multicolumn{2}{|c|}{$\begin{array}{l}\text { Serum Folate } \\
(m \mu g . / m l .)\end{array}$} & \multicolumn{2}{|c|}{$\begin{array}{l}\text { Serum Vitamin } B_{13} \\
(\mu \mu \mathrm{g} . / \mathrm{ml} .)\end{array}$} \\
\hline & $>4$ & $<4$ & $>150$ & $<150$ \\
\hline No. of patients & 29 & 13 & 36 & 7 \\
\hline $\mathbf{L D H} \pm \mathbf{I S D}$ & 404 & $420 \pm 173$ & $404 \pm 185$ & $397 \pm 170$ \\
\hline
\end{tabular}

TABLE V

SERUM FOLATE, VITAMIN $B_{12}$, AND LDH IN PATIENTS AFTER PARTIAL GASTRECTOMY

No. of patients

Serum vitamin $B_{12}$ ( $\mu \mu \mathrm{g} . / \mathrm{ml}$.)

No. of patients

Serum folate $(\mathrm{m} \mu \mathrm{g} . / \mathrm{ml}$.)

\begin{tabular}{|c|c|}
\hline$>500$ & $<500$ \\
\hline $\begin{array}{l}7 \\
266 \pm 131\end{array}$ & $\begin{array}{l}20 \\
273 \pm 88\end{array}$ \\
\hline $\begin{array}{l}10 \\
5 \cdot 3 \pm 2 \cdot 7\end{array}$ & $\begin{array}{l}19 \\
6 \cdot 1 \pm 2 \cdot 7\end{array}$ \\
\hline
\end{tabular}


finding might be expected when it is considered that the LDH originates in the megaloblasts of the bone marrow and then passes to the peripheral blood (Elliott and Fleming, 1965). The LDH produced by a few megaloblastic cells might not be adequate to raise the peripheral LDH levels. Studies on the bone marrow LDH might have been more rewarding in these patients as elevation of LDH levels would first be detectable here. From our results it may be concluded that LDH estimation does not offer a simple means of detecting minor megaloblastic changes but minor megaloblastic change may not be significant, particularly in the presence of iron deficiency.

The decision as to whether megaloblastic anaemia is due to folic acid or vitamin $\mathbf{B}_{12}$ deficiency is sometimes difficult. In such instances it may be necessary to carry out a therapeutic trial with physiological amounts of folic acid and to assess response by means of daily reticulocyte counts. Daily LDH estimations would seem to be at least as valuable as reticulocyte counts in assessing the response to a therapeutic trial of folic acid. In two patients, cases 8 and 9, who had combined vitamin $B_{12}$ and folic acid deficiency, a reticulocyte response was accompanied by a fall in LDH value. The LDH values in these patients did not, however, fall to normal, as they would if folic acid deficiency alone was present. From the partial return towards normal of LDH values it was possible to diagnose the combined deficiency which could not be detected from reticulocyte response alone. In one patient (case $\stackrel{7}{7}$ ), who did not appear to have an associated folic acid deficiency, a reticulocyte response occurred whirh was not accompanied by a fall in LDH so perhapsin this patient the LDH was superior to the reticulocyte count in assessing the response. The six patients whth vitamin $\mathrm{B}_{12}$ deficiency alone showed no depression of LDH or increase in reticulocyte count during the period of the trial whereas the patients with folic a $\overrightarrow{\mathrm{ebd}}$ deficiency showed a rapid fall towards normal.

From Tables IV and V it is clear that low serim levels of vitamin $B_{12}$ or folic acid are not of themselves accompanied by elevated LDH values nor are the few LDH values above 500 in normal patiefits accompanied by altered $B_{12}$ or folic acid levels.

We wish to thank Dr. J. R. Clamp and Dr. A. B. Rager for their help in this study and their advice with the writmg of this report.

\section{REFERENCES}

Berger, L., and Broida, D. (1964). Technical bulletin, No. 500 (revised). Sigma.

Elliott, B. A., and Fleming, A. F. (1965). Brit. med. J., 1, 626. Fleming, A. F., and Elliott, B. A. (1964). Ibid., 2, 1108.

Hess, B. (1963). Enzymes in Blood Plasma, Academic Press, New Y Kohn, J., Mollin D. L., and Rosenbach, L. M. (1961). J. clin. P(gh. 14, 345. 